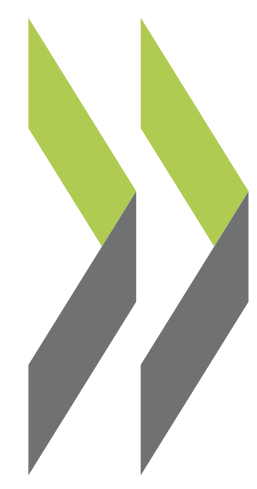

OECD Economics Department Working Papers No. 390

Channels for Narrowing the US Current Account Deficit and Implications for Other Economies

Anne-Marie Brook, Franck Sédillot, Patrice Ollivaud 
Organisation de Coopération et de Développement Economiques

Organisation for Economic Co-operation and Development

18-May-2004

ECONOMICS DEPARTMENT

English - Or. English

CHANNELS FOR NARROWING THE US CURRENT ACCOUNT DEFICIT AND IMPLICATIONS FOR OTHER ECONOMIES

ECONOMICS DEPARTMENT WORKING PAPERS No 390

By Anne-Marie Brook, Franck Sédillot and Patrice Ollivaud

All Economics Department Working Papers are now available through OECD's Internet Web site at http://www.oecd.org 


\section{ABSTRACT/RESUME}

\section{Channels for narrowing the US current account deficit and implications for other economies}

In this paper the OECD's interlink model is used to explore several possible channels through which a narrowing of the US current account deficit could occur. The shocks considered include dollar depreciation, fiscal consolidation, and an improvement in the non-price competitiveness of US producers. A key conclusion is that shocks would have to be very large in order to materially reduce the US external deficit. In part, this is because second-round effects, including domestic policy responses, tend to offset the shocks' initial impact. In addition, it is clear that each of the channels for narrowing the deficit involves risks to growth in the rest of the world, particularly in Japan where the authorities have limited room to use monetary or fiscal policy to offset any contractionary pressures. The exchange rate simulations highlight the fact that more exchange rate flexibility in Asia would spread the burden of adjustment more evenly across US trading partners. Attention is also drawn to the increased risk of deflation posed by significant fiscal consolidation at a time of unusually low interest rates. This risk would, however, be mitigated if the fiscal consolidation were to occur in conjunction with an inflationary shock, such as significant dollar depreciation. Finally, higher growth rates in US trading partners are estimated to improve the US current account balance only minimally.

JEL classification: $\mathrm{F} 32, \mathrm{~F} 42, \mathrm{~F} 47$

Keywords: current account adjustment, international transmission, simulations

$* * * * *$

\section{Des canaux permettant de réduire le déficit de la balance courante américaine et leurs implications pour les autres économies}

Dans cette étude, le model Interlink de l'OCDE est utilisé pour étudier quelques moyens permettant de réduire le déficit courant américain. Les chocs considérés inclus une dépréciation du dollar, une consolidation fiscale et une amélioration de la compétitivité hors-prix des producteurs américains. Un des principaux enseignements de cette étude est que les chocs doivent être suffisamment importants pour diminuer de façon significative le déficit courant des États-Unis. Ceci est dû en partie au fait que les effets de second tour, incluant politiques économiques nationales, tendent à compenser l'impact du choc initial. En plus, chacun des chocs étudiés se traduit par des risques sur la croissance des autres régions du monde, particulièrement au Japon ou la marge de manoeuvre des autorités monétaire et budgétaire pour contrebalancer les pressions récéssionistes est limitée. Les simulations du taux de change soulignent qu'une plus grande flexibilité du taux de change en Asie permettrait de partager le coût de l'ajustement plus équitablement entre les principaux partenaires commerciaux des États-Unis. Une attention particulière est donnée aux risques de déflation induits par une consolidation fiscale à un moment ou les taux d'intérêt sont particulièrement bas. Ce risque est toutefois moins aigu si une telle consolidation fiscale intervient en conjonction avec un choc inflationniste, tel qu'une dépréciation significative du dollar. Finalement, une activité plus soutenue chez les partenaires commerciaux américains n'améliore la balance courante des États-Unis que de façon marginale.

JEL codes : F32, F42, F47

Mots-clés : ajustement du compte courant, transmission internationale, simulations

\section{Copyright OECD, 2004}

Applications for permission to reproduce or translate all, or part of, this material should be made to: Head of Publications Service, OECD, 2 rue André-Pascal, 75775 Paris Cédex 16, France. 


\section{TABLE OF CONTENTS}

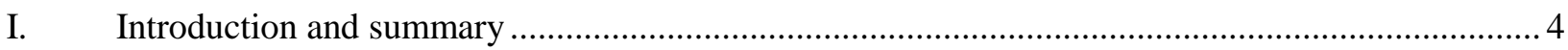

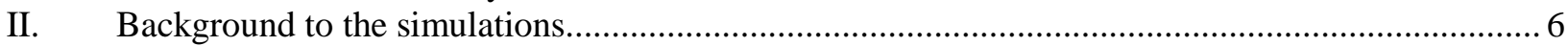



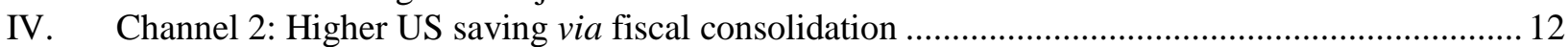

V. Channel 3: Increase in US export share via supply-side improvement ........................................ 17





\section{Boxes}

1. The elasticity asymmetry in the United States: explanations and possible channels for reversal .. 19

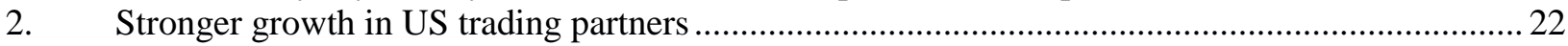




\title{
CHANNELS FOR NARROWING THE US CURRENT ACCOUNT DEFICIT AND IMPLICATIONS FOR OTHER ECONOMIES
}

\author{
Anne-Marie Brook, Franck Sédillot and Patrice Ollivaud ${ }^{1}$
}

\section{Introduction and summary}

1. The US current account deficit recently peaked at its highest level ever recorded -- around 5.2 per cent of GDP -- and, although it has fallen slightly since, it remains very high by historical standards (Figure 1). For a large economy like the United States, a deficit of this magnitude absorbs a significant proportion of total world savings and implies an increasing share of US assets in foreign investors' portfolios. While the United States remains an attractive investment destination in many respects, it is uncertain for how long foreigners will continue to accumulate debt and equity claims against US residents at the current pace, ${ }^{2}$ suggesting that the timing of the narrowing of the deficit is uncertain. When the deficit does narrow, however, it will have implications both within and outside the United States, with specific effects depending on the channels of adjustment. This paper considers several possible adjustment channels with a view to tracing through the implications of each for growth prospects in the major OECD economies.

2. The main adjustment channels evaluated are dollar depreciation, fiscal consolidation, and an improvement in the non-price competitiveness of US exports. The possible role of stronger growth in US trading partners is also considered. For each channel, simulations conducted using the OECD's Interlink model are used to trace through the cross-country linkages and other implications.

3. An evaluation of the channels reveals that, in each case, a relatively large shock is required to achieve a modest (2 percentage points of GDP) improvement in the US trade balance. There are a number of reasons for this. To start with, the second-round effects from domestic policy responses often serve to offset the impact of the initial shock, thus resulting in a more muted impact on the current account balance than one might have expected. For example, a large fiscal consolidation requires a significant drop in short-term interest rates (to offset negative effects on activity and inflation), which in turn prompts a decline in the private saving ratio, and this offsets much of the initial gain in public saving. Feedback effects from the rest of the global economy can also have an offsetting impact. For example, dollar depreciation has a contractionary impact on US trading partners, reducing their demand for US exports.

1. The authors wish to thank Jørgen Elmeskov, Mike Feiner, Mike Kennedy, Vincent Koen, Nigel Pain, Pete Richardson and other members of the Economics Department for useful comments on previous drafts of this paper. They also thank Catherine Lemoine and Laure Meuro for technical assistance. The views expressed are those of the authors and do not necessarily reflect the views of the OECD or its member countries.

2. Unfortunately there is no simple metric by which to judge the sustainability of current account deficits. Among other things, sustainability would depend on the appropriate share of US dollar assets in investors' portfolios, the perceived riskiness of the United States as a borrower, and the relative attractiveness of other investment destinations. It is likely that the United States' ability to finance its external deficit in a reserve currency implies a higher sustainability limit than for other similar economies. Yet the deficits are still of growing concern because they add to the stock of outstanding debt that could become increasingly difficult to finance (e.g. see Greenspan $(2003,2004))$. See also Mann $(1999,2002)$ for further discussion of the concept of sustainability. 
Figure 1. The US current account in historical perspective

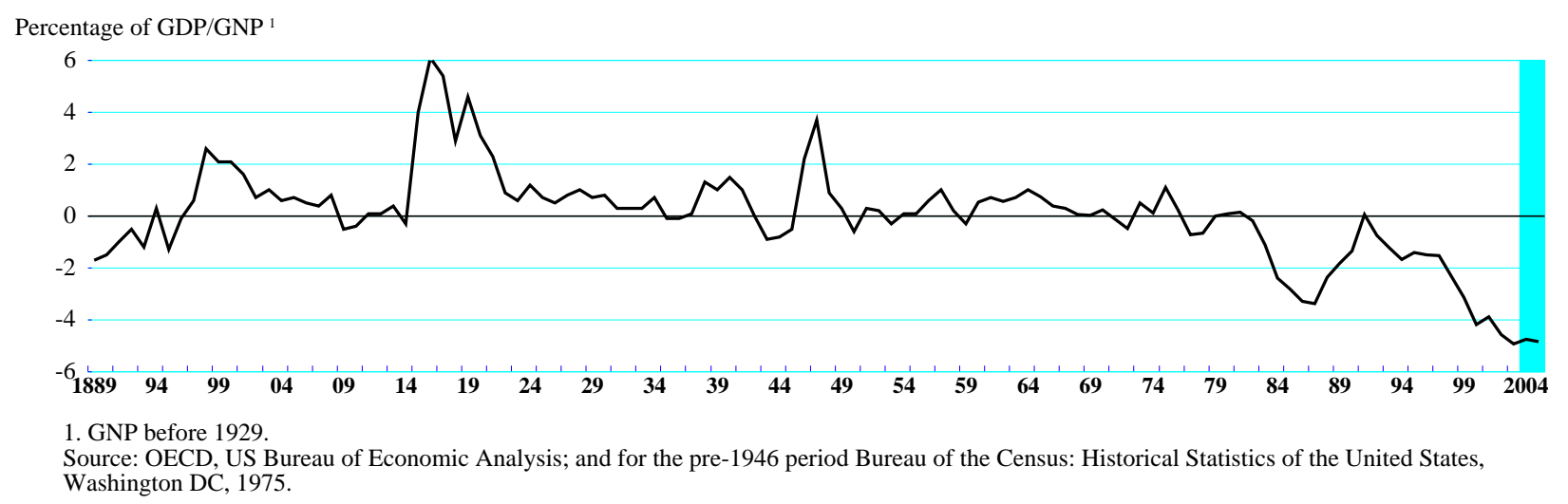

4. Some key implications of the paper are as follows:

- Even a modest narrowing of the US current account deficit would require large changes to exchange rates, fiscal policy or the non-price competitiveness of US exports. This would pose significant risks to growth in US trading partners -- not least in Japan, given the limits that the authorities face with respect to using monetary or fiscal policy to offset any contractionary pressures.

- The impact of dollar depreciation on other OECD economies would depend importantly on the flexibility of exchange rates in the Asian region. If the renminbi and other currencies remain tied (either formally or informally) to the dollar as it falls, then the costs to Japan and other OECD economies would be greater than if the dollar is permitted to fall against all other currencies.

- The positive effect of fiscal consolidation on the current account deficit would be partly offset by a decline in private saving. In addition, current starting points suggest a greater-than-normal risk of short-term interest rates being pushed close to the zero nominal interest rate bound. Such a risk would, however, be mitigated if the fiscal consolidation were to occur in conjunction with higher inflation or a large dollar depreciation, provided it had an inflationary effect.

- An autonomous gain in US non-price export competitiveness via structural change on the supply side of the US economy would represent a positive outcome for the United States, and be the least costly for other OECD countries.

- More generally, it seems difficult to imagine a scenario that would significantly narrow global imbalances without imposing some costs on the rest of the world. For example, even a permanent 0.5 percentage point increase in annual productivity growth in all OECD economies outside of the United States would improve the US current account balance only minimally.

5. At present, there is little evidence of stress in funding the US current account deficit; interest rates in the United States remain relatively low, demand for new US debt securities is quite strong and exchange rate changes have been orderly to date. Yet, ongoing signs of trade protectionism -- in the United 
States and elsewhere -- suggest that there may be unforeseen costs of continued significant imbalances and corresponding benefits of adjustment. ${ }^{3}$

\section{Background to the simulations}

6. In the case of each adjustment channel, shocks were overlaid on the OECD's December 2003 medium-term baseline ${ }^{4}$ to achieve an improvement in the US trade balance of around 2 percentage points of GDP after six years. The impact on the net investment income balance, and therefore on the current account deficit, differs between the simulations according to the path of interest rates and the implications for debt-servicing payments that accrue to non-residents. Since the Interlink model does not embody an explicit central bank reaction function, all scenarios were calibrated to incorporate a monetary policy response which ensures that inflation will ultimately return to baseline level. The implications of each scenario for key economic variables in the United States, Japan and the euro area are summarized in tables throughout the paper.

7. In this paper, the implications of a narrowing of the trade deficit by 2 per cent of GDP are discussed. Whether this magnitude of adjustment would be necessary or sufficient is difficult to discern. However, the implications for US external debt can be calculated. At present, US net foreign liabilities are equal to around 25 per cent of GDP, which is relatively low by comparison with many other OECD countries. If the current account deficit were to remain at 5 per cent of GDP each year, with nominal GDP growing at an annual rate of 5 per cent in the baseline, net foreign liabilities would steadily rise, eventually stabilising at around 100 per cent of GDP in the long run. ${ }^{5}$ If instead the current account deficit were to narrow from 5 per cent to 3 per cent of GDP, net foreign liabilities would stabilise at around 60 per cent of GDP (Figure 2). Of course, the results of such calculations are very dependent on the assumption for GDP growth, and still do not answer the question of what level of current account deficit, or net international investment position, would be sustainable.

Figure 2. Net US foreign assets

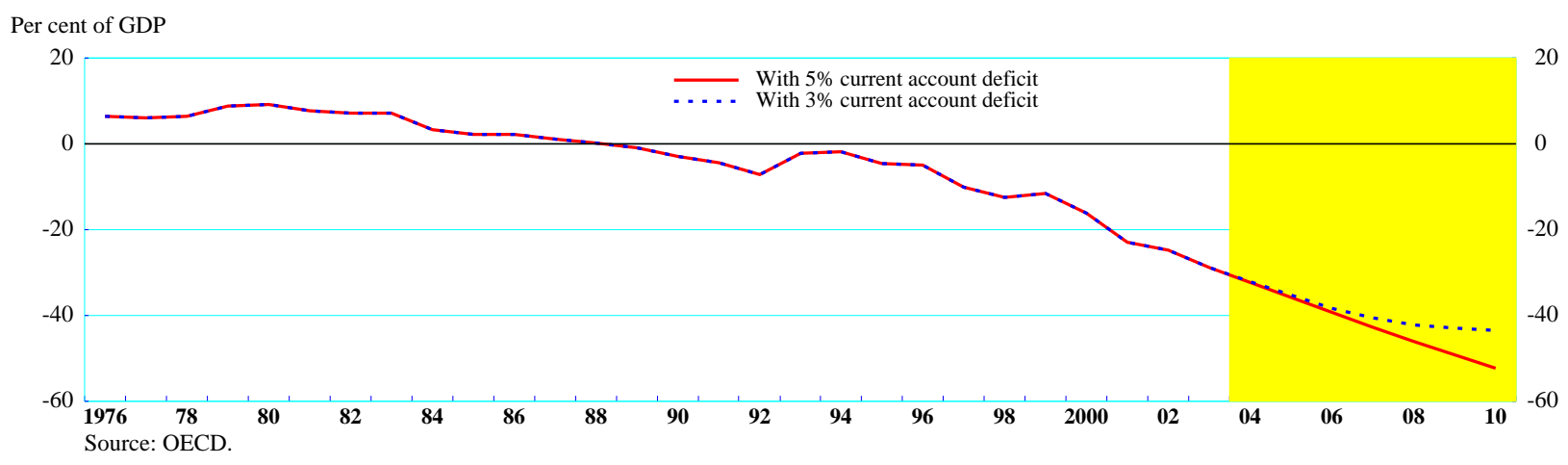

3. Any new protectionist initiatives are particularly dangerous in the context of wide current account imbalances, at which time the flexibility of the global economy becomes even more important (Greenspan, 2003, 2004).

4. See Downes et al., 2003.

5. See the Appendix for a derivation of the steady state relationship between the current account and debt. 


\section{Channel 1: Exchange rate adjustment}

8. Exchange rate changes have long been perceived as perhaps the key mechanism for achieving current account adjustment. In economies with floating exchange rates, the process is typically driven by market participants. As foreign investors become less willing to fund the increasing shortfall between total saving and total investment at existing exchange rates, there is downward pressure on the currency. In the United States, this has happened to some extent since the dollar peaked in February 2002, although pressure has been mitigated by the significant capital flows from Asian central banks, motivated, in part, by a desire to prevent significant exchange rate movements relative to the dollar.

9. Historically, the observed bilateral relationship between countries' exchange rate and their current account balance has differed across countries. In some cases, large exchange rate depreciations have been associated with a significant reversal of current account deficits. For example, after the real effective exchange rate of Canada fell by around 25 per cent over the 1990s, the Canadian current account balance swung from a persistent deficit to a surplus of around 2 per cent. Similarly, as the real effective exchange rate of Sweden fell by over 20 per cent after 1992, the current account balance swung from a deficit of more than 3 per cent of GDP to a surplus of around 4 per cent. Over the same period, however, both countries underwent substantial fiscal consolidation that may also have affected the external balance. In other cases, large nominal exchange rate changes have not been accompanied by much adjustment. For example, in economies where inflation expectations have been poorly anchored, persistent real exchange rate depreciation has proved difficult to achieve, with nominal exchange rate depreciation being offset by higher inflation relative to that in trading partners. ${ }^{6}$

10. In the United States, the observed historical relationship between the real exchange rate of the US dollar and the current account balance is negative (Figure 3). The causal relationships driving this feature of the data are multiple, however. For example, relative buoyancy of US domestic demand may at times have been associated with both a large deficit and substantial capital inflows. But direct links from the exchange rate to the external balance probably also played a role. There are, however, a number of factors that limit the extent of current account improvement in response to exchange rate depreciation. First, the link between the two involves a delay. Second, there is evidence that pricing to market is significant. Indeed, evidence suggests that exchange-rate pass-through into import prices is relatively low in the United States compared with other OECD countries.

11. Third, since any dollar depreciation will be mirrored by exchange rate appreciation elsewhere, there will be a contractionary impact on the economies of US trading partners creating a negative feedback effect on demand for US exports. In current circumstances, this effect is likely to be particularly strong for economies such as Japan that are limited in the extent to which they can offset the negative demand shock with more stimulatory monetary or fiscal policy. ${ }^{8}$

6. For example, although the Italian lira fell by almost 20 per cent over the 1980s and 1990s, neither the real effective exchange rate nor the current account balance had any real trend.

7. This is true for both short- and long-term pass-through elasticities (Campa and Goldberg, 2002).

8. The Japanese authorities have been using quantitative targets to ease monetary policy beyond the level suggested by zero interest rates, but this channel is not captured in the simulations. Thus, the simulations also do not capture any possible impact on the yen from quantitative easing. 
Figure 3. Real effective exchange rate and the current account balance in the United States

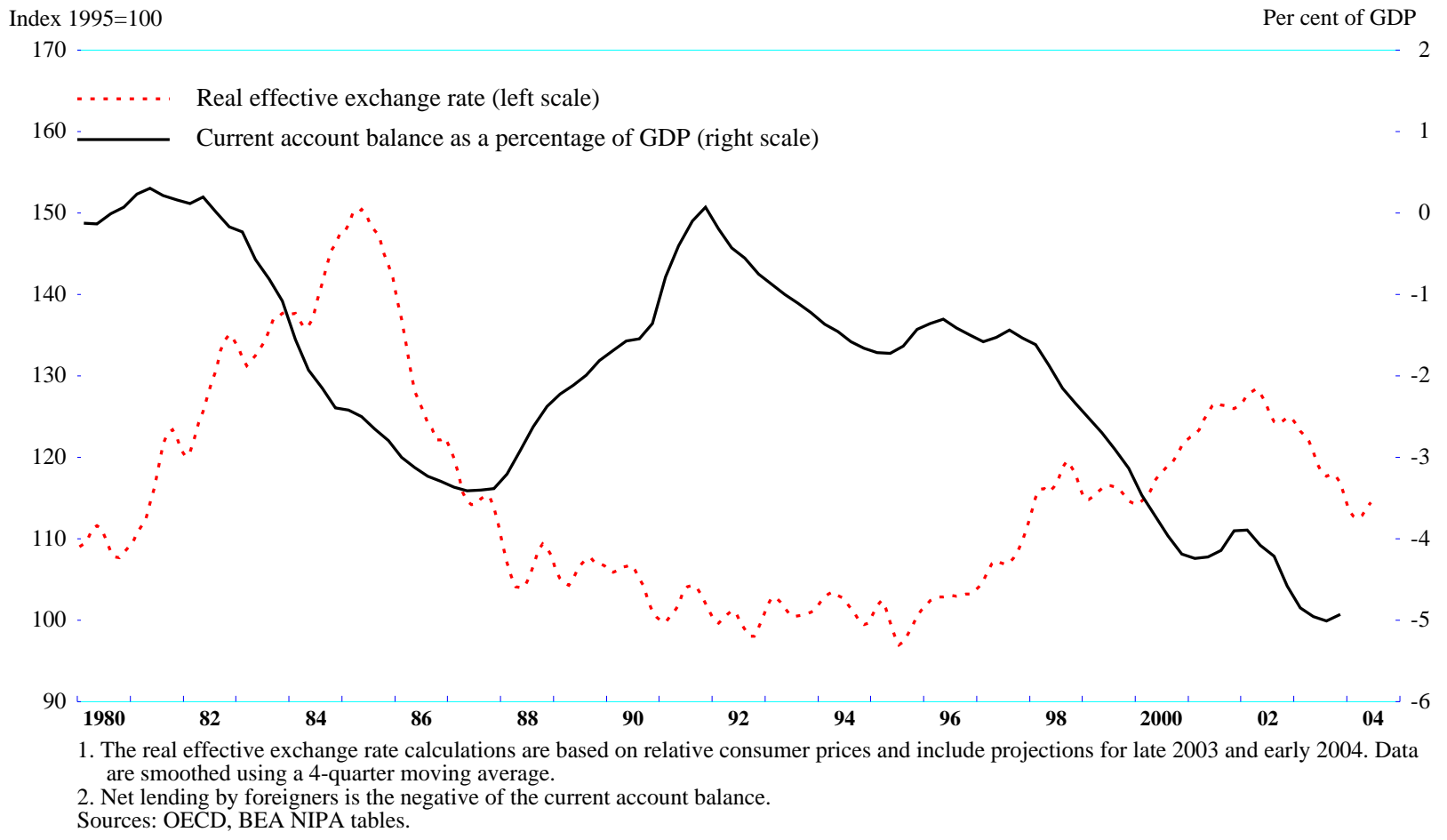

12. Finally, depending on the extent to which a fall in the dollar pushes up US inflation, monetary policy will have to respond, and interest rates would rise. ${ }^{9}$ Higher interest payments on foreign-held debt would then suggest that the improvement in the current account deficit would be less than that in the US trade balance.

13. These factors are illustrated by the first two scenarios, which evaluate the impact of a 22.5 per cent nominal depreciation in the effective dollar exchange rate. The depreciation is assumed to occur over the first year of the projection horizon. ${ }^{10}$ In Scenario 1A this depreciation is made up of a 30 per cent decline relative to other OECD exchange rates, and no change relative to exchange rates in the non-Japan Asia region (see Figure 4 for the currency weights in the US real effective exchange rate). In Scenario 1B the dollar depreciation is spread more evenly: around 22 per cent against all currencies. ${ }^{11}$ The implications

9. Higher short-term policy interest rates would tend to push up bond yields also, and this could be expected to have a downward impact on US house prices and share prices. However, such asset price effects are not explicitly taken into account in these simulations.

10. The scenarios should be viewed as primarily illustrative for a number of reasons. First, the depreciation is simply imposed in a clinical fashion, without regard to any specific event, or series of events, which may prompt the depreciation and which would have additional impacts of their own. Second, it is (unrealistically) assumed that the dollar moves equally against all currencies. Another simplification is the assumption of no wealth effects outside of the United States, related to capital losses on bond portfolios (foreign holders of US securities being hit by exchange rate valuation changes in addition to lower bond prices). Similarly, it is also assumed that there are no wealth effects within the United States from capital gains on the value of foreign currency asset holdings.

11. The scenario is slightly unrealistic in that it assumes that the dollar moves equally against all currencies. In practice, countries with a very high exposure to the United States (such as Canada) would probably experience less bilateral movement. 
of each shock for the effective exchange rates of the euro area and Japan are summarised in Table 1. Adding column A to column C or D provides the implied total depreciation or appreciation, since the peak in the dollar in February 2002.

\section{Figure 4. US real effective exchange rate weights}

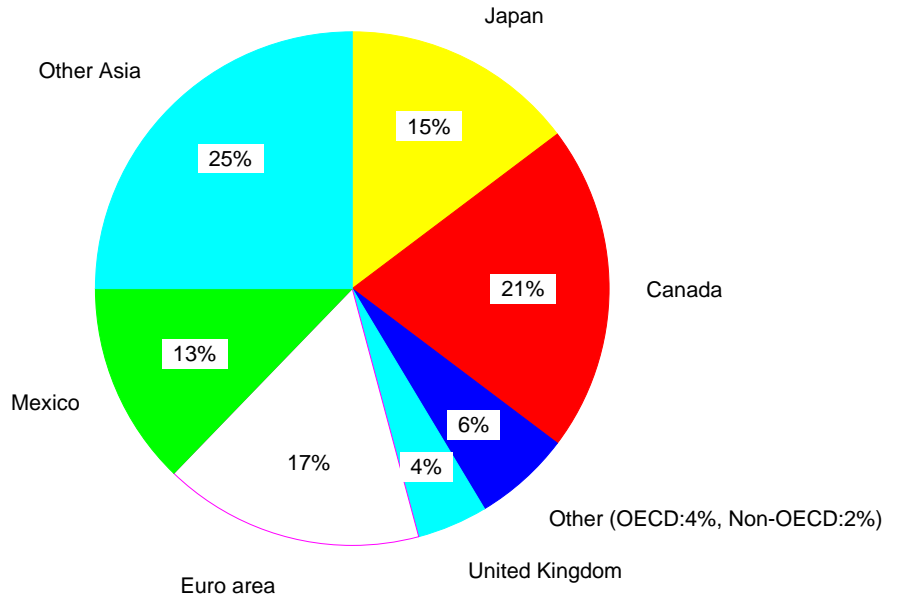

Source : OECD.

Table 1. Implied exchange rates in Scenarios $1 \mathrm{~A}$ and $1 \mathrm{~B}$

\begin{tabular}{cccc}
\multicolumn{4}{c}{ Effective exchange rates (percentage appreciation) } \\
\hline $\begin{array}{c}\text { from USD peak } \\
\text { (Feb 2002) to EO74 }\end{array}$ & $\begin{array}{c}\text { from USD peak } \\
\text { (Feb 2002) to 16 Apr 2004 }\end{array}$ & Scenario 1A & Scenario 1B \\
$(\boldsymbol{A})$ & $(B)$ & $(\boldsymbol{C})$ & $($ D) \\
-10.1 & -11.6 & -22.5 & -22.5 \\
10.9 & 12.3 & 22.0 & 5.5 \\
16.3 & 18.9 & 11.0 & 4.0
\end{tabular}

Note: The cut-off date for exchange-rate movements for the baseline was early November 2003 (published in the OECD Economic Outlook, No.74, December 2003)

a) Both scenarios involve a 221/2 per cent effective dollar depreciation. In Scenario $1 \mathrm{~A}$ (inflexible non-OECD Asia) this is achieved through a 30 per cent dollar depreciation relative to OECD currencies, and in Secario 1B (full exchange-rate flexibility), the $22 \frac{1}{2}$ per cent depreciation is spread evenly across all currencies.

Source: OECD. 
Figure 5. Real effective exchange rate and scenarios

Index $1995=100$



Index $1995=100$

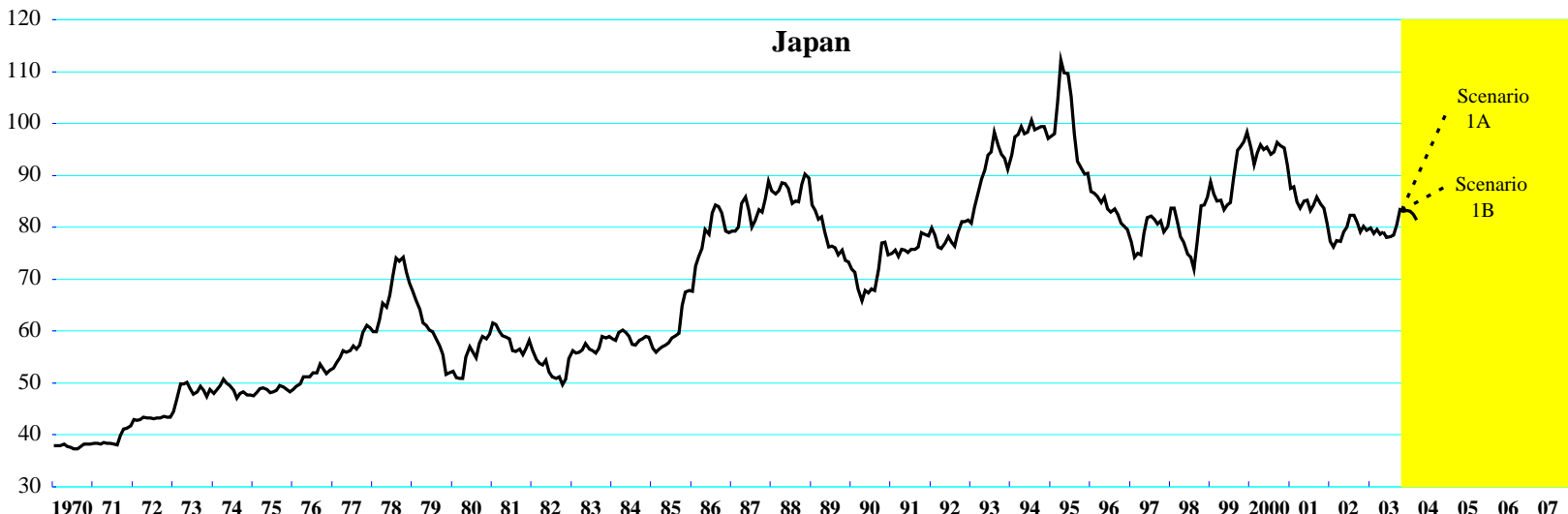

Index $1995=100$



$\begin{array}{lllllllllllllllllllllllllllllllllllllllll}1970 & 71 & 72 & 73 & 74 & 75 & 76 & 77 & 78 & 79 & 80 & 81 & 82 & 83 & 84 & 85 & 86 & 87 & 88 & 89 & 90 & 91 & 92 & 93 & 94 & 95 & 96 & 97 & 98 & 99 & 2000 & 01 & 02 & 03 & 04 & 05 & 06 & 07\end{array}$

Note : Calculations of the real effective exchange rate (based on relative CPI inflation) include projections for 2004. The effective euro area exchange rate prior to 1999 is synthetic

Note that these figures combine the assumed 'nominal' exchange rate shocks from Scenarios 1A and 1B with the historical path of the 'real' effective

exchange rate. However, movements in the real effective exchange rates over the projection period would differ depending on relative inflation differentials. For example, the extent of real dollar depreciation would be somewhat eroded by higher inflation in the United States relative to that in other countries.

Source : OECD. 
14. While large, the extent of dollar depreciation assumed is not unprecedented. For example, between 1985 and 1988 the effective US exchange rate fell by 32 per cent, with a very gradual further decline after that taking the total depreciation to 36 per cent by 1995, a decline broadly similar to the shock imposed in the simulated dollar depreciation (Figure 5). ${ }^{12}$ However, whereas the depreciation in the 1980s pushed the dollar back to previous lows, a drop of this magnitude from the peak of the exchange rate cycle in February 2002 would take it to new record lows, although this could be consistent with the trend deterioration in the current account balance. Other researchers, using very different models, similarly conclude that the exchange rate changes required for a significant improvement in the US current account position could be substantial. ${ }^{13}$

15. The corresponding exchange rate appreciation of the yen and euro would also be dramatic -- particularly in Scenario 1A (Figure 5). While these exchange rates would not breach historical peaks on an effective basis, difficulties in compiling synthetic trends in the euro exchange rate prior to 1999 introduce some uncertainties regarding the accuracy of historical comparisons. And in the case of the yen, Scenario 1A suggests that it would appreciate to levels last seen only briefly in 1995 and widely considered at that time to be punitively high.

16. For the United States, the economic impact of Scenarios 1A and 1B is very similar, reflecting that the same magnitude of effective depreciation occurs in both cases. The fall in the dollar pushes up US inflation, prompting a tightening of monetary policy and a rise in short-term interest rates of 300 basis points. In the short term, inflation reaches about 3 per cent before gradually declining back towards baseline. The US trade balance slowly improves, with corresponding deteriorations in the trade balances of other regions (Table 2).

17. For the euro area and Japan, the impact of the two shocks varies significantly -- particularly for Japan which has a much larger trade exposure to the United States and the rest of Asia than does the euro area. Whereas the exchange rate shock in Scenario 1A is equivalent to a 22 per cent appreciation in the effective yen exchange rate, in Scenario 1B it is just 6 per cent (Table 1). In the baseline, where there is no room for reductions of policy-controlled interest rates in Japan, the impact of the shock in Scenario 1A results in weaker growth and more pronounced deflation, whereas these effects are more mild in Scenario 1B. Relative to baseline, Japan's current account surplus declines by around 2 per cent of GDP in Scenario 1A, versus less than 1 per cent in Scenario 1B. However, the recent tendency for deflation to abate and more recent projections of positive inflation in Japan in the future suggest that the baseline, and therefore the simulations, may be unduly negative.

18. In the euro area, the impact is milder than in Japan for two reasons. First, the euro area is less exposed to the United States and non-Japan Asia. In fact the effective euro exchange rate appreciates by only 11 per cent in Scenario 1A and by just 4 per cent in Scenario 1B (Table 1). Second, the euro-area monetary authorities have the ability to cut policy rates sufficiently to offset the contractionary impulse in both scenarios.

12. Note that Figure 5 combines the assumed nominal effective exchange rate change from the scenario with historical data for the real effective change rate. However, movements in the real effective exchange rates over the projection period would differ depending on domestic inflation rates relative to inflation rates in trading partners. For example, the extent of real dollar depreciation would be somewhat eroded by higher inflation in the US relative to that in non-OECD countries.

13. See, for example, Obstfeld and Rogoff (2000). 


\begin{tabular}{|c|c|c|c|c|c|}
\hline & \multicolumn{3}{|c|}{ Average 2004-09 } & \multicolumn{2}{|c|}{$\begin{array}{c}\text { End point (2009): scenario relative to } \\
\text { baseline }\end{array}$} \\
\hline & $\begin{array}{c}\text { Dec. } 2003 \\
\text { Baseline }\end{array}$ & Scenario $1 A^{a}$ & Scenario $1 B^{a}$ & Scenario $1 A^{a}$ & Scenario $1 B^{a}$ \\
\hline \multicolumn{6}{|l|}{ United States } \\
\hline Real GDP (growth/ level) ${ }^{b}$ & 3.3 & 3.3 & 3.3 & -0.5 & -0.3 \\
\hline Prices (inflation/ price level) ${ }^{b}$ & 1.3 & 2.6 & 2.2 & 7.6 & 5.1 \\
\hline Trade balance ${ }^{c}$ & -4.7 & -3.4 & -3.4 & 2.0 & 1.9 \\
\hline Current account balance ${ }^{c}$ & -5.1 & -4.2 & -4.3 & 1.4 & 1.3 \\
\hline Short-term interest rates ${ }^{d}$ & 392 & 692 & 692 & 300 & 300 \\
\hline \multicolumn{6}{|l|}{ Japan } \\
\hline Real GDP (growth/ level) ${ }^{b}$ & 1.6 & 1.3 & 1.4 & -2.1 & -1.4 \\
\hline Prices (inflation/ price level) ${ }^{b}$ & -0.2 & -1.2 & -0.5 & -5.7 & -1.7 \\
\hline Trade balance ${ }^{c}$ & 2.6 & 1.6 & 2.7 & -1.8 & -0.6 \\
\hline Current account balance ${ }^{c}$ & 5.0 & 3.6 & 4.7 & -2.0 & -0.8 \\
\hline Short-term interest rates ${ }^{d}$ & 13 & 13 & 13 & 0 & 0 \\
\hline \multicolumn{6}{|l|}{ Euro area } \\
\hline Real GDP (growth/ level) ${ }^{b}$ & 2.3 & 2.3 & 2.3 & -0.2 & -0.1 \\
\hline Prices (inflation/ price level) ${ }^{b}$ & 1.6 & 1.4 & 1.5 & -1.2 & -0.6 \\
\hline Trade balance $^{c}$ & 2.5 & 1.1 & 1.7 & -2.2 & -1.6 \\
\hline Current account balance ${ }^{c}$ & 1.0 & 0.1 & 0.7 & -1.5 & -1.0 \\
\hline Short-term interest rates ${ }^{d}$ & 358 & 208 & 308 & -150 & -50 \\
\hline $\begin{array}{l}\text { a) Both scenarios involve a } 22.5 \mathrm{p} \\
\text { currencies and in Scenario1B th }\end{array}$ & $\begin{array}{l}\text { lollar dep } \\
\text { epreciatio }\end{array}$ & $\begin{array}{l}\text { In Scenario 1A } \\
\text { d evenly across }\end{array}$ & $\begin{array}{l}\text { achieved through } \\
\text { rrencies. }\end{array}$ & r cent depreciatio & ive to $\mathrm{OECD}$ \\
\hline $\begin{array}{l}\text { b) Numbers in first three columns at } \\
\text { consumption deflator. }\end{array}$ & $\mathrm{s}$ of change; $\mathrm{n}$ & in last two colun & low the level in 2 & lative to baseline. & refer to the \\
\hline c) In per cent of GDP. & & & & & \\
\hline d) Basis points. & & & & & \\
\hline
\end{tabular}

19. It is difficult to accurately determine how changes in exchange rates and interest rates will be reflected in the net investment income balance. Here a simplified rule of thumb is that one-third of the rise in US debt servicing accrues to non-residents. Thus, since the exchange rate scenarios incorporate an increase in domestic interest rates, the US current account deficit improves by significantly less (around 1.4 percentage points, relative to baseline) than the trade balance (up 2.0 percentage points). ${ }^{14}$

\section{Channel 2: Higher US saving via fiscal consolidation}

20. Based on national accounting identities, the current account deficit is equal to the shortfall of national saving relative to domestic investment. Thus, an increase in the national saving rate, ceteris paribus, would be reflected in a narrowing of the external deficit. The specific impact on the current account deficit of a tightening in fiscal policy depends on the extent to which increases in government saving are offset by declines in private saving. There are a number of channels via which this offset may occur. One of these involves ex post financial "crowding in" whereby fiscal consolidation prompts lower

14. Another effect, not captured here, is the fact that dollar depreciation would raise the dollar-denominated return on US foreign-currency assets. This effect would improve the investment income balance, mitigating the impact of higher debt servicing costs. 
real interest rates, which in turn prompts a decline in the private saving ratio or a boost to private investment.

21. Another channel may involve negative exante effects on private saving related to gains in confidence or "Ricardian equivalence" effects associated with the fiscal consolidation. ${ }^{15}$ The conditions under which co-movements in private and public saving are fully offsetting (such as under full Ricardian Equivalence) are unlikely to be realised in practice. But there is still significant evidence that private saving moves to at least partially offset changes in public saving. ${ }^{16}$ Recent manifestations of the negative relationship have included the improvement in the US fiscal position during the 1990s, which was associated with a significant decline in private saving, and the more recent deterioration in the fiscal position which has been associated with a rise in private saving (Figure 6). In both cases, however, the interactions between private and public saving were complex.

22. As a result of the private sector saving offset, a relatively large improvement in fiscal positions is normally required to achieve a noticeable effect on the current account balance. This is illustrated in Scenario 2A, which assumes a 6 percentage point improvement in the fiscal deficit, relative to baseline, phased in gradually over the six-year horizon. ${ }^{17}$ This takes the fiscal balance from a deficit of almost 5 per cent of GDP in 2003 to a surplus of 1.7 per cent of GDP after six years. As with the other scenarios, this shock improves the trade balance by 2 percentage points of GDP.

23. The magnitude of fiscal consolidation assumed in Scenario 2A is large, although not so large as to take the fiscal balance into unchartered territory. Indeed, the experience of both the United States and other countries since the early 1990s, suggests that consolidations of such a magnitude have not been particularly unusual (Table 3). In some of the previous cases of large fiscal contractions, the consolidation was achieved over a slightly longer time period than the six-year horizon assumed in Scenario 2, although there are still several examples of very large improvements in the fiscal position over a six-year horizon.

15. Ricardian equivalence refers to the situation where an increase (reduction) in public savings is fully offset by lower (higher) private sector savings, due to economic agents discounting the lower (higher) taxes which will be needed to pay for government borrowing, thus leaving net private sector wealth unchanged.

16. See de Mello et al. (2004) and de Serres and Pelgrin (2003). In the work reported by de Mello et al., a correlation of -0.6 is found between changes in private saving and the cyclically-adjusted budget balance in the United States. They also find that fiscal actions are subject to diminishing returns in the sense that the larger the fiscal impulse, the larger the private saving offset. Similarly, de Serres and Pelgrin find that private-sector savings rates respond significantly to changes in public-sector savings, although again the degree of offset is estimated to be considerably less than unity.

17. The fiscal consolidation is achieved via a cut in public expenditures equivalent to 1.5 per cent of nominal GDP, combined with an increase in tax revenues equivalent to 4.5 per cent of nominal GDP, phased in gradually over the six-year horizon. Half of the total fiscal consolidation is achieved by increasing indirect tax revenues (up by 3 per cent of GDP), while direct tax revenues increase by 1.5 per cent of GDP. 
Figure 6. The composition of savings in the United States
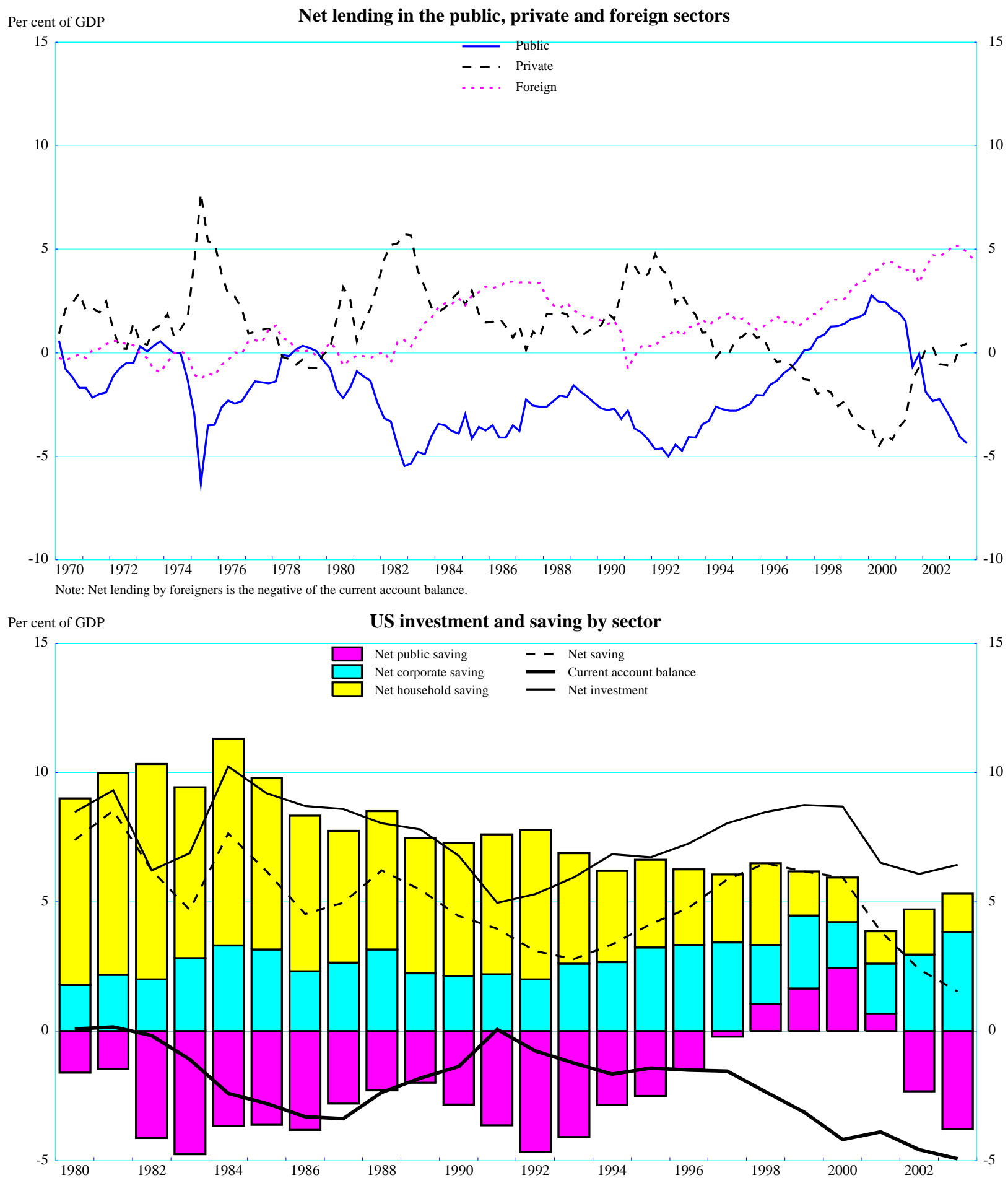

Note: Net saving and investment data is from the National Income and Product Accounts. Thus, there is a statistical discrepancy between the current account balance and net foreign saving defined as the gap between net saving and net investment.

Sources: OECD, BEA NIPA tables. 
Table 3. Episodes of large fiscal consolidation and interest rate levels

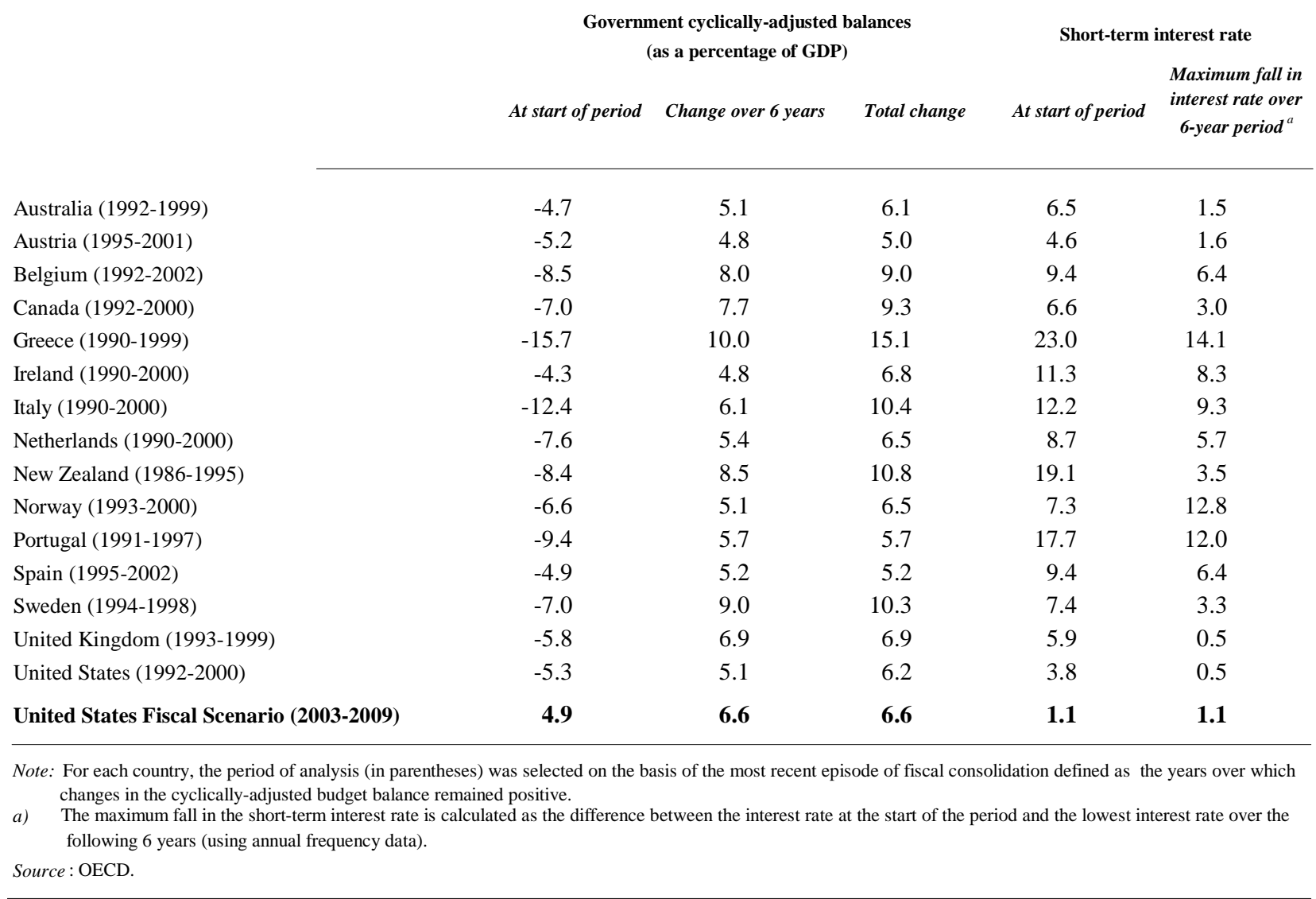

24. In Scenario 2A around two thirds of the higher public saving is offset by lower private saving. This offset stems primarily from the monetary policy response. Since the fiscal shock is contractionary, it is assumed that short-term interest rates are cut significantly, providing some offsetting stimulus to domestic demand. ${ }^{18}$ Thus, although household disposable income falls by around 10 per cent relative to baseline, consumption only declines by about 7 per cent, with a drop in the private saving rate of nearly 4 per cent of disposable income. With corporations in a similar position, the total private saving rate falls by around 4 percentage points of GDP, relative to baseline. In terms of saving and investment balances, therefore, most of the improvement in the current account balance is achieved via an increase in total saving, although a slight fall in total investment also plays a role (Table 4). The significant negative correlation between public and private saving rates that has been observed historically persists. ${ }^{19}$

18. Long-term interest rates would also tend to fall. In fact, given the reduction in the future supply of US bonds, portfolio allocation factors would likely reduce long-term interest rates by more than short-term rates. It is also possible that a credible fiscal consolidation could result in a lower risk premia on long-term interest rates.

19. The degree of offset in private saving in response to the rise in public saving may differ according to the composition of changes to expenditure and taxes. In general, however, the experience of OECD economies suggests that fiscal restraint has an offsetting impact on private saving regardless of whether it is driven by expenditure cuts or tax increases (de Mello et al., 2004). 
Table 4. Fiscal consolidation scenarios: key results

\begin{tabular}{|c|c|c|c|c|c|}
\hline & & Average 2004-0 & & End point $(200$ & $\begin{array}{l}\text { nario relative to } \\
\text { e }\end{array}$ \\
\hline & Dec. 2003 Baseline & Scenario $2 A^{a}$ & Scenario $2 B^{b}$ & Scenario $2 A^{a}$ & Scenario $2 B^{b}$ \\
\hline United States & & & & & \\
\hline Real GDP (growth/ level) ${ }^{c}$ & 3.3 & 2.6 & 2.8 & -4.5 & -3.2 \\
\hline Prices (inflation/ price level) ${ }^{c}$ & 1.3 & 1.6 & 1.8 & 1.5 & 3.1 \\
\hline Government net lending $^{d}$ & -4.7 & -0.9 & -1.7 & 5.9 & 4.2 \\
\hline Primary government net lending ${ }^{d}$ & -2.6 & 0.2 & -0.4 & 4.4 & 3.1 \\
\hline Private saving $^{d}$ & 14.2 & 11.6 & 12.7 & -3.8 & -1.9 \\
\hline Private investment ${ }^{d}$ & 16.1 & 16.0 & 16.1 & -0.4 & -0.3 \\
\hline Trade balance $^{d}$ & -4.7 & -3.7 & -3.4 & 2.1 & 2.1 \\
\hline Current account balance $^{d}$ & -5.1 & -3.8 & -3.6 & 2.6 & 2.5 \\
\hline Short-term interest rates ${ }^{e}$ & 392 & 0 & 125 & -540 & -300 \\
\hline Japan & & & & & \\
\hline Real GDP (growth/ level) ${ }^{c}$ & 1.6 & 1.3 & 1.2 & -2.0 & -2.2 \\
\hline Prices (inflation/ price level) ${ }^{c}$ & -0.2 & -0.7 & -1.1 & -2.7 & -5.0 \\
\hline Trade balance $^{c}$ & 2.6 & 2.2 & 1.9 & -1.3 & -1.8 \\
\hline Current account balance $^{d}$ & 5.0 & 4.5 & 4.0 & -1.3 & -2.0 \\
\hline Short-term interest rates ${ }^{e}$ & 13 & 13 & 13 & 0 & 0 \\
\hline Euro area & & & & & \\
\hline Real GDP (growth/ level) ${ }^{c}$ & 2.3 & 2.2 & 2.2 & -0.4 & -0.5 \\
\hline Prices (inflation/ price level) ${ }^{c}$ & 1.6 & 1.7 & 1.5 & 1.0 & -0.4 \\
\hline Trade balance ${ }^{d}$ & 2.5 & 1.9 & 1.4 & -1.4 & -1.9 \\
\hline Current account balance $^{d}$ & 1.0 & 0.3 & 0.0 & -1.5 & -1.8 \\
\hline Short-term interest rates ${ }^{e}$ & 358 & 246 & 171 & -150 & -225 \\
\hline
\end{tabular}

a) Scenario $2 \mathrm{~A}$ involves an increase in direct and indirect tax revenues of 3 and 1.5 per cent of nominal GDP respectively; and a cut in public expenditures of 1.5 per cent of real GDP.

b) Scenario 2B involves a 15 per cent dollar depreciation relative to OECD country exchange rates; an increase in direct tax revenues of 2 per cent of nominal GDP; and a cut in public expenditures of 2 per cent of real GDP. Prices refer to the consumption deflator.

c) Numbers in first three columns are annual rates of change; numbers in last two columns show the level in 2009 relative to baseline.

d) In per cent of GDP

e) Basis points.

25. Importantly, because of the very low starting points for inflation and interest rates in the United States, there would also be a risk of deflation in response to such a large fiscal contraction, and this might impose limits on the extent to which fiscal policy consolidation can be tightened, even aside from political considerations. In the absence of any positive confidence effects fiscal consolidation is contractionary and the normal monetary policy response, ceteris paribus, would be to lower short-term interest rates. But with the starting point for policy rates very low, this may raise the risk of short-term interest rates being pushed close to the zero nominal interest rate bound.

26. For example, in Scenario 2A short-term interest rates are cut to zero. Thus, although inflation remains stable, the loss of further room for manoeuvre on short-term interest rates suggests that there would be an increased risk of deflation -- for example, if the economy was to face another contractionary shock at the same time. Of course, this problem would be mitigated to the extent that there is "crowding in" from the private sector, or "Ricardian" type effects, ${ }^{20}$ although in that case -- if the private saving rate

20. In the simulations, no additional allowance was made for confidence effects, or for "Ricardian" behaviour. 
fully offset the rise in the public saving rate -- there would be no improvement in the current account balance. Other countries that have achieved such large fiscal consolidations all started with significantly more room for easing monetary policy than the United States has at present. In practice, of course, the extent to which this room for monetary easing has been used has varied (see right-hand column in Table 3) depending on the nature of the fiscal contraction and the extent to which other economic drivers offset any contractionary effects from fiscal policy.

27. This deflationary risk would be mitigated if fiscal consolidation were to occur in conjunction with significant dollar depreciation, provided it had inflationary effects. Such a combined shock is imposed in Scenario 2B: the fiscal deficit is assumed to close by $2009^{21}$ (versus a surplus of almost 2 per cent of GDP in Scenario 2A), and the dollar to depreciate by 15 per cent relative to other OECD currencies. ${ }^{22}$ Since the expansionary impact of the depreciation compensates for much of the contractionary impact of the fiscal tightening, the need for monetary policy easing is lessened, and short-term nominal interest rates are permitted to climb gradually over the forecast horizon, rather than being cut to zero. As in each of the previous scenarios, the trade balance improves by 2 percentage points of GDP. However, the current account balance improves by even more, reflecting the fact that interest rates are significantly lower than in the baseline.

28. The negative spill-over effects to US trading partners in Scenario 2A are the result of a fall in US demand for their exports. In Scenario 2B there is an additional effect from the exchange rate change. Thus, these economies would suffer more negative effects on output and net exports than in the case where the same improvement in the US trade balance was achieved through fiscal consolidation alone. For the euro area, the simulation results show that an assumed cut in interest rates helps to maintain domestic demand despite the fall in net exports. In Japan, where the baseline allows little room for manoeuvre on monetary policy, the implications are more severe, with lower growth rates and a worsening of deflation. Both the Japanese and euro-area trade balances deteriorate by around 2 percentage points of GDP in Scenario 2B versus around 1 1/2 percentage points in Scenario $2 \mathrm{~A}$.

\section{Channel 3: Increase in US export share via supply-side improvement}

29. An important explanation for the trend deterioration in the US trade deficit is the seemingly greater appetite that US consumers have for imports relative to foreigners' appetite for US exports. This feature shows up in the estimated income elasticities for US imports of goods and services which are typically larger than the foreign income elasticities for US exports of goods and services (Table 5). As long as this elasticity asymmetry persists, the US trade deficit will continue to deteriorate, for a given level of the terms of trade, even if the economies of US trading partners are growing at the same pace as the US economy. Indeed, this trend is a large part of the reason why many other possible channels for improving the current account balance have so little impact.

21. The fiscal contraction in Scenario 2B is achieved by a cut in public expenditures and an increase in direct tax revenues, each equivalent to 2 percentage points of nominal GDP.

22. The less flexible exchange rates of the Asian region are assumed to remain tied to the US dollar. This exchange rate shock is therefore equivalent to a shock of half the magnitude imposed in Scenario $1 \mathrm{~A}$. 
Table 5. Selected estimates of income elasticities for the United States

\begin{tabular}{|c|c|c|c|c|c|}
\hline & \multirow{2}{*}{ Data period } & \multicolumn{2}{|c|}{ Exports of: } & \multicolumn{2}{|c|}{ Imports of: } \\
\hline & & Goods & Services & Goods & Services \\
\hline Pain and van Welsum (2004) ${ }^{a}$ & $1987-2000$ & & 1.7 & & \\
\hline Mann $(2003)^{b}$ & $1976-2000$ & & 2.1 & & 1.5 \\
\hline Wren-Lewis and Driver (1998) & 1980-1995 & 1.21 & 1.95 & 2.36 & 1.72 \\
\hline \multirow[t]{2}{*}{ Houthtakker and Magee (1969) } & $1951-1966$ & 0.99 & & 1.51 & \\
\hline & & \multicolumn{2}{|c|}{$\begin{array}{l}\text { Exports of goods } \\
\text { and services }\end{array}$} & \multicolumn{2}{|c|}{$\begin{array}{l}\text { Imports of goods } \\
\text { and services }\end{array}$} \\
\hline Mann $(2003)^{c}$ & $1976-2000$ & \multicolumn{2}{|c|}{1.4} & \multicolumn{2}{|c|}{2.2} \\
\hline Hooper, Johnson and Marquez (1998) & $1960-1996$ & \multicolumn{2}{|c|}{0.80} & \multicolumn{2}{|c|}{1.80} \\
\hline Cline (1989) & $1973-1987$ & \multicolumn{2}{|c|}{1.70} & \multicolumn{2}{|c|}{2.44} \\
\hline \multicolumn{6}{|l|}{ Memorandum item: } \\
\hline \multicolumn{2}{|l|}{ Elasticities in OECD Interlink Model } & \multicolumn{2}{|c|}{$1.8^{d}$} & \multicolumn{2}{|c|}{2.2} \\
\hline \multicolumn{6}{|c|}{$\begin{array}{l}\text { a) This number is calculated as a weighted average of Pain and van Welsum's estimates of elasiticities for individual categories } \\
\text { of services. Their estimates use total world trade in non-government services as the measure of foreign demand rather than } \\
\text { foreign GDP (as used in the other studies). However, the number quoted in this table has been scaled up to reflect the } \\
\text { relatively slower growth in world GDP versus world trade in services. Thus this number is comparable with the others in the } \\
\text { table. }\end{array}$} \\
\hline \multicolumn{6}{|c|}{$\begin{array}{l}\text { b) These numbers are calculated as a weighted average of Mann's (2003) estimates of the income elasticity of Other personal } \\
\text { services, and the estimates by Stern et al. (2001) of income elasticities for the Travel, Passenger fares and Other } \\
\text { transportation components of total services. }\end{array}$} \\
\hline \multicolumn{6}{|c|}{$\begin{array}{l}\text { c) These numbers are a weighted average of Mann's income elasticities for services and Wren-Lewis and Driver's (1998) } \\
\text { estimates of the income elasticities for goods. }\end{array}$} \\
\hline \multicolumn{6}{|c|}{$\begin{array}{l}\text { d) Note that the export elasticity in the OECD model is normally quoted as } 1.0 \text {, based on a weighted average of growth in } \\
\text { foreign imports as the measure of foreign demand, rather than foreign GDP. However, the number quoted in this table has } \\
\text { been adjusted for the effect of the denominator in order to ensure comparability with the other numbers in the table. }\end{array}$} \\
\hline
\end{tabular}

30. There are a number of explanations for the elasticity asymmetry in the United States, several of which also suggest possible channels for reversing it and thereby the trend in the deficit (see Box 1). One such channel would involve the US economy continuing to build on its comparative advantage in the production of many "new-economy" services, where the elasticities are more favourable for the United States. Additionally, it is possible that US out-performance in productivity growth, relative to most other OECD economies, will result in the production of a wider range of high quality goods. Such outcomes capture the role of supply-side determinants of US export market share and would imply improved competitiveness for the United States, which would help to reverse the recent decline in US export performance. Although the specific policies that might influence non-price competitiveness are less clearcut than for the first two channels, this channel provides a useful framework for considering some of the additional determinants of US trade performance that are not captured in Scenarios 1 and 2 and thereby also for assessing the possibility that adjustment may occur without recourse to those first two channels. 


\section{Box 1. The elasticity asymmetry in the United States: explanations and possible channels for reversal}

While the reported range is wide (Table 5) there is a general consensus that estimated income elasticities for US imports of goods and services are significantly greater than the foreign income elasticities for US exports of goods and services. This is known as the Houthakker-Magee elasticity asymmetry. ${ }^{1}$ This box examines four possible explanations for the asymmetry. One of these stresses the role of demographics. Younger populations tend to consume a relatively higher proportion of imports, and fewer domestic services such as health care, while immigrants tend to maintain their tastes for products from home. ${ }^{2}$ Indeed, there is some evidence that when the age distribution of domestic residents and the proportion of immigrants are incorporated as explanatory variables, the income elasticity for US imports is reduced. ${ }^{3}$

A second explanation stresses the role of supply factors in the exports of the United States' dynamic trading partners (e.g. in Asia). As first documented by Krugman (1989), there is a tendency for countries with higher growth rates to produce a greater variety and quality of goods for export, which in turn increases the foreign demand for those countries' products (or, equivalently, the elasticity of demand for imports from those countries). This supply effect is sufficiently important that it might account for around half the magnitude of estimated income elasticities of US import demand. When the supply effect is subtracted, the "unbiased" income elasticity of US import demand is estimated to be less than 1, which no longer implies that preferences for imports are not homothetic (or that traded goods are luxuries). ${ }^{4}$

Third, there are a number of other factors that also help to explain the US elasticity asymmetries. These include the role of production relocation and vertical integration, and improvements in global and regional market access. Indeed, there is some evidence that these additional factors can be captured by a non-linear time trend, in which case a unitary elasticity of US imports with respect to income is accepted by the data. ${ }^{5}$

The fourth explanation focuses on the composition of US trade, and the differences in estimated elasticities across sectors. Although there is a range of estimates, there is some evidence that the elasticity asymmetry is present only for trade in goods. For total services the effect is reversed, with estimates of the elasticity of demand for exports of services consistently higher than estimates of the elasticity of demand for imports of services. ${ }^{6}$ The implication seems to be that the United States has more of a comparative advantage in the production of services (particularly new economy services), ${ }^{7}$ than goods. If this is true then further liberalization of trade in services, together with deeper investment in new economy services by US trading partners, would increase the size of this sector within US trade, and thus narrow the overall asymmetry.

1. After Houthakker and Magee (1969) -- the first to document the trend.

2. Immigrants also tend to contribute to the current account deficit by sending home remittances.

3. Marquez (2002).

4. Using a standard model of trade elasticities, Gagnon (2003) estimates a US income elasticity of demand for imports of 1.5. However, when the model is re-specified to exclude the supply effect, the estimated elasticity drops to 0.75. Even accounting for the fact that Gagnon's initial estimate is at the low end of the range of estimates (see Table 5 for others), this explanation has the potential to account for a large proportion of the asymmetry, if not all of it.

5. E.g. see Pain and van Welsum (2004) and Pain and Wakelin (1998).

6. See estimates in Table 5 by Mann (2003) and Wren-Lewis and Driver (1998).

7. See Mann (2003). New economy services are those professional services (such as architecture, engineering and consulting) that information technology increasingly allows to be traded across borders. 
In terms of import elasticities, the range of explanatory factors makes it difficult to extrapolate from future income growth to future import growth. For example, the first three explanations for the elasticity asymmetry (for trade in goods) suggest that to some extent the estimated coefficients may just be picking up other effects, such as the role of supply factors abroad. If so, then the future path of US imports may depend at least as much on the non-price competitiveness of the dynamic Asian economies, than on the growth of income in the United States.

The explanations discussed above suggest two main channels for narrowing or reversing the elasticity asymmetry. The first would involve an expansion of services exports. The second would involve continued strong productivity growth in the United States, accompanied by a pick-up in the variety and quality of goods and services for export.

However, there are a number of risks to this scenario. Importantly, further liberalization of trade in new economy services, where the elasticities seem to be favourable for the United States, may be hindered by protectionist pressures. Indeed, US efforts to restrict international outsourcing of low-skilled services may prompt international retaliation in the area of trade in new economy services. Another risk, from the perspective of the US trade balance, is that deeper integration of new economy services may enable US trading partners to produce a greater variety and quality of goods for export. In other words, a new economy and accompanying "Krugman-type" elasticity effects in Europe or Japan could directly offset the assumed supply-side improvement in US export performance. ${ }^{8}$

8. Although Mann (2003) considers the combined impact of a narrowing in the elasticity asymmetry and higher productivity growth in US trade partners, she does not consider the possibility of "Krugman" effects in those countries. Instead she considers only the additional demand-side boost to US exports from higher trading partner growth.

31. In Scenario 3, it was found that a 2 per cent of GDP improvement in the US trade deficit, achieved solely through improved non-price-driven gains in US export competitiveness, would require that the share of US goods in world imports increase by around 2 percentage points over the next six years. There would also be a reduction in the US import penetration ratio (Figure 7). Within the model, this shock was also roughly equivalent to a reversal of the asymmetry in US elasticities of demand, with the new elasticities being phased in gradually over a six-year horizon. ${ }^{23}$ The left-hand panel of Figure 7 shows the extent of increase in US export market share. While this is a relatively modest increase, it should be noted that the previous increase in market share occurred in conjunction with exchange rate depreciation. The magnitude of the required adjustment in Scenario 3 looks more extreme when evaluated in terms of the elasticity changes required.

23. The export elasticities in the OECD model relate export sales to market demand as calculated by a weighted measure of import volumes in US trading partners. Thus, the simulation was conducted by doubling the foreign demand elasticity of US exports (from 1.0 to 2.0) and halving the US income elasticity of imports (from 2.2 to 1.0). However, the export elasticities from the other studies quoted in Table 5 use the slower-growing foreign GDP as the measure of market size instead. When scaled up to represent comparable numbers, the OECD simulation therefore implies a doubling of the foreign income elasticity of US exports (from 1.8 to 3.6). While this magnitude of increase seems implausibly large, it was the required magnitude to achieve the target 2 per cent of GDP improvement in the US trade balance. However, it is unclear how well this shock proxies for the more general supply-side determinants that this scenario attempts to capture. 
Figure 7. US market performance

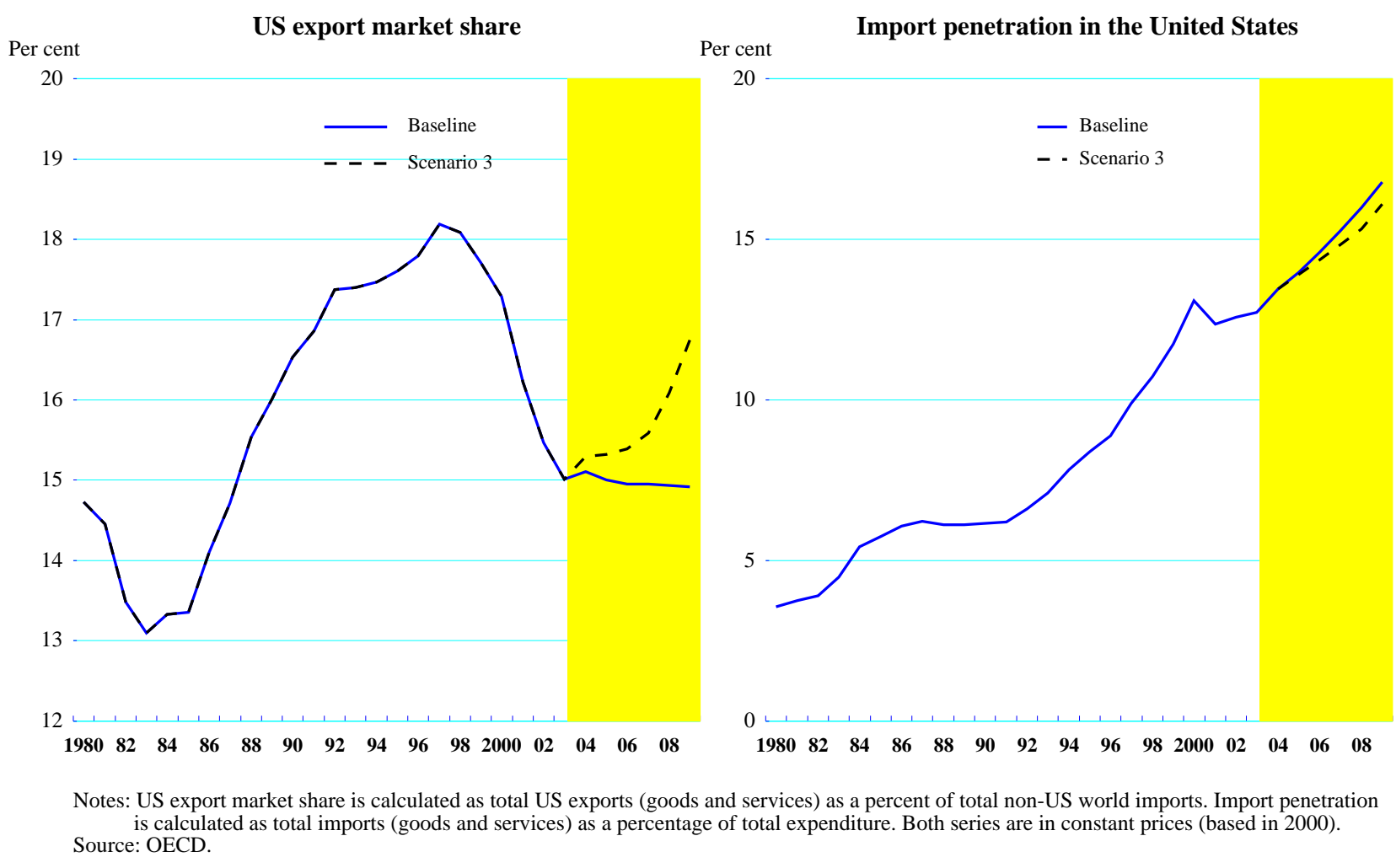

Figure 8. Growth in export market performance for major OECD economies and Ireland (Average annual growth rates)

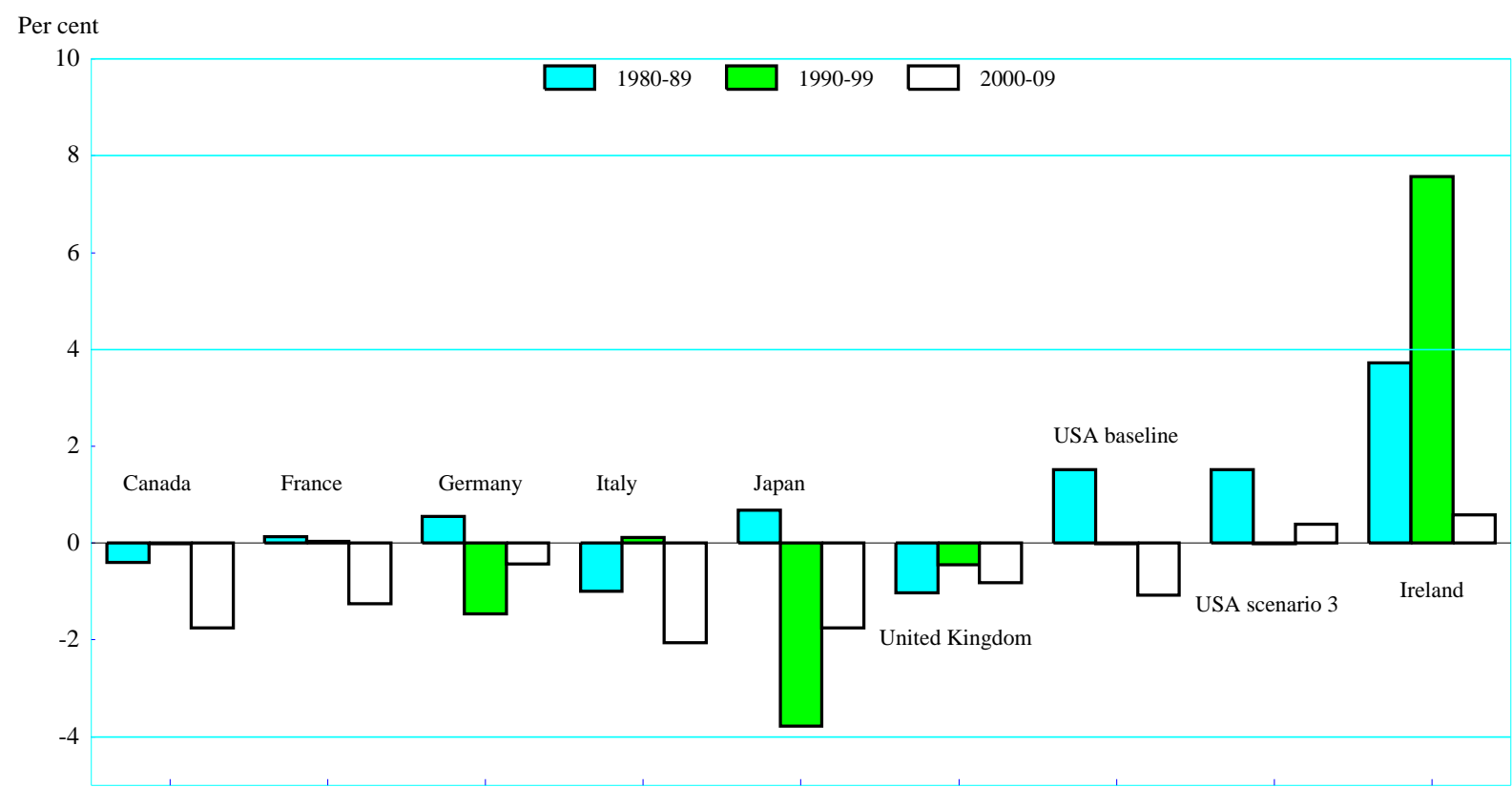

Note: Export market performance is an index of exports relative to weighted import demand in trading partners. Source: OECD. 
32. Although the United States has lost market share over recent years, it has tended to perform well in this area relative to the other major OECD economies. However, much faster growth in market performance is recorded for economies that are "catching up", such as Ireland (Figure 8). ${ }^{24}$ Thus, while the assumed recovery of US export market share would distinguish US performance relative to other similar economies, it may not be implausible in the context of strong growth in services exports and strong productivity growth driving continued innovation in both goods and services exports.

Table 6. Elasticity reversal scenario: key results

\begin{tabular}{|c|c|c|c|}
\hline & \multicolumn{2}{|c|}{ Average 2004-09 } & \multirow{2}{*}{$\begin{array}{c}\text { End point (2009): scenario } \\
\text { relative to baseline } \\
\text { Scenario } 3^{a}\end{array}$} \\
\hline & MTB74 Baseline & Scenario $3^{a}$ & \\
\hline \multicolumn{4}{|l|}{ United States } \\
\hline Real GDP (growth/ level) ${ }^{b}$ & 3.3 & 3.6 & 1.6 \\
\hline Prices (inflation/ price level) ${ }^{b}$ & 1.3 & 1.7 & 0.0 \\
\hline Government net lending $^{c}$ & -4.7 & -4.7 & 5.9 \\
\hline Primary government net lending ${ }^{c}$ & 0.0 & 0.2 & 4.4 \\
\hline Trade balance $^{c}$ & -4.7 & -3.9 & 1.8 \\
\hline Current account balance $^{c}$ & -5.1 & -4.3 & 1.8 \\
\hline Short-term interest rates ${ }^{d}$ & 392 & 467 & 100 \\
\hline \multicolumn{4}{|l|}{ Japan } \\
\hline Real GDP (growth/ level) ${ }^{b}$ & 1.6 & 1.4 & -1.2 \\
\hline Prices (inflation/ price level) ${ }^{b}$ & -0.2 & -0.6 & 0.0 \\
\hline Trade balance ${ }^{c}$ & 2.6 & 2.2 & -1.1 \\
\hline Current account balance $^{c}$ & 5.0 & 4.6 & -1.0 \\
\hline Short-term interest rates ${ }^{d}$ & 13 & 13 & 0 \\
\hline \multicolumn{4}{|l|}{ Euro area } \\
\hline Real GDP (growth/ level) ${ }^{b}$ & 2.3 & 2.2 & -0.7 \\
\hline Prices (inflation/ price level) ${ }^{b}$ & 1.6 & 1.6 & 0.0 \\
\hline Trade balance $^{c}$ & 2.5 & 2.0 & -1.0 \\
\hline Current account balance $^{c}$ & 1.0 & 0.5 & -0.9 \\
\hline Short-term interest rates ${ }^{d}$ & 358 & 308 & -50 \\
\hline \multicolumn{4}{|c|}{ a) Foreign demand elasticity of US exports raised from 1.0 to 2.0; income elasticity of US imports lowered from 2.2 to 1 . } \\
\hline \multicolumn{4}{|c|}{ b) Numbers in first two columns are annual rates of change; numbers in last column show the level in 2009 relative to baseline. } \\
\hline \multicolumn{4}{|l|}{ c) In per cent of GDP. } \\
\hline d) Basis points. & & & \\
\hline
\end{tabular}

33. Since the boost to US net exports in Scenario 3 is expansionary, it is assumed that policy rates are tightened by up to 100 basis points. Although the export competitiveness of US trading partners is hurt, the impact of this is partially offset by increased demand from a strong US economy. In addition the simulations suggest that the ability to use monetary policy to bolster domestic demand (policy rates in the

24. The market performance index that is utilised to calculate the growth rates in Figure 8 varies slightly from the measure of export market share that is illustrated in Figure 7. Export market share is calculated as a percentage of total non-US exports whereas the export performance indices use a weighted average of imports in trading partners. 
euro area are assumed to be reduced by 50 basis points) could compensate for the fall in externally-led growth, although there would obviously still be a significant change in composition away from externallyled growth and towards domestic demand. Since Japan is more limited in its ability to use monetary or fiscal policy to offset the contractionary pressures, further deflation and weaker GDP growth result (Table 6). ${ }^{25}$

34. Compared with the previous two scenarios, Scenario 3 is the least costly scenario for US trading partners, even though GDP in these economies is still adversely affected. The only possible exception to the general principle that a narrowing in the US current account deficit hurts US trading partners, would be stronger growth in US trading partners. Yet Box 2 suggests that even that would not make a substantial difference.

\section{Box 2. Stronger growth in US trading partners}

It is often argued that much of the decline in the US current account balance could be reversed by higher growth in the economies of US trading partners. The additional scenario discussed in this box, however, suggests that the benefits for the US trade balance from this channel are relatively mild. This scenario considers the impact of a permanent 0.5 percentage point increase in annual TFP growth and domestic demand, in non-US OECD countries. This roughly halves the gap between potential output growth in the United States (approximately 3.0 per cent per annum) and in the euro area (1.8 per cent per annum in the baseline). The gap with Japan also narrows significantly.

In this scenario, growth in the euro area and Japan is boosted significantly. Because the additional growth is assumed to derive equally from supply and demand, there are no associated inflationary pressures. As a result, no monetary policy response is required. Yet despite the fact that the increase in demand outside the United States implies higher market growth, the overall improvement to the US trade balance is only 0.2 per cent of GDP by 2009 (Table 7).

There are a couple of reasons for this. First, there is a second-round impact of higher US exports on US import demand. Since the US import elasticity with respect to US income is greater than unity, stronger export growth also implies stronger imports. Given these model parameters, the impact of stronger trading partner growth can only be made more potent by narrowing or reversing the elasticity asymmetry. However, even if this shock was combined with such a narrowing of the US elasticity asymmetry, there would be the risk (from the perspective of the US trade balance) that positive productivity shock outside of the United States would produce "Krugman" type effects on the trade elasticities of US trading partners, thus offsetting the initial benefits to the United States. ${ }^{1}$

1. See Box 1 for more discussion of this point.

25. As noted earlier, the recent tendency for deflation to abate and more recent OECD projections showing positive inflation in Japan further ahead suggest that these simulations, which are based on a baseline where deflation continues until 2009 , could be unduly negative. 
Table 7. Faster growth in US trading partners: key results

\begin{tabular}{|c|c|c|c|}
\hline & \multicolumn{2}{|c|}{ Average 2004-09 } & \multirow{2}{*}{$\begin{array}{c}\text { End point (2009): scenario relative } \\
\text { to baseline } \\
\text { Stronger growth in trading } \\
\text { partners }^{a}\end{array}$} \\
\hline & \multirow[t]{2}{*}{$\begin{array}{c}\text { MTB74 } \\
\text { Baseline }\end{array}$} & \multirow[t]{2}{*}{$\begin{array}{l}\text { Stronger growth in trading } \\
\text { partners }{ }^{a}\end{array}$} & \\
\hline United States & & & \\
\hline Real GDP $(\text { growth/ level })^{b}$ & 3.3 & 3.4 & 0.2 \\
\hline Consumption deflator (inflation/ price level) ${ }^{b}$ & 1.3 & 1.4 & 0.0 \\
\hline Trade balance ${ }^{c}$ & -4.7 & -4.5 & 0.2 \\
\hline Current account balance ${ }^{c}$ & -5.1 & -5.0 & 0.2 \\
\hline Short-term interest rates ${ }^{d}$ & 392 & 392 & 0 \\
\hline \multicolumn{4}{|l|}{ Japan } \\
\hline Real GDP (growth/ level) ${ }^{b}$ & 1.6 & 2.1 & 3.1 \\
\hline Consumption deflator (inflation/ price level) ${ }^{b}$ & -0.2 & -0.3 & 0.0 \\
\hline Trade balance ${ }^{c}$ & 2.6 & 2.8 & 0.3 \\
\hline Current account balance ${ }^{c}$ & 5.0 & 5.1 & 0.3 \\
\hline Short-term interest rates ${ }^{d}$ & 13 & 13 & 0 \\
\hline \multicolumn{4}{|l|}{ Euro area } \\
\hline Real GDP (growth/ level) $)^{b}$ & 2.3 & 2.8 & 3.0 \\
\hline Consumption deflator (inflation/ price level) ${ }^{b}$ & 1.6 & 1.6 & 0.0 \\
\hline Trade balance $e^{c}$ & 2.5 & 2.4 & -0.3 \\
\hline Current account balance ${ }^{c}$ & 1.0 & 0.9 & -0.2 \\
\hline Short-term interest rates ${ }^{d}$ & 358 & 358 & 0 \\
\hline \multicolumn{4}{|c|}{ a) Permanent 0.5 per cent increase in ex ante domestic demand growth plus permanent 0.5 per cent increase in TFP growth in non-US OECD. } \\
\hline \multicolumn{4}{|c|}{ b) Numbers in first two columns are annual rates of change; numbers in last column show the level in 2009 relative to baseline. } \\
\hline \multicolumn{4}{|l|}{ c) In per cent of GDP. } \\
\hline d) Basis points. & & & \\
\hline
\end{tabular}




\section{APPENDIX: STABILISING THE FOREIGN DEBT RATIO}

In the steady state, the current account balance that is required to stabilise the net debt-to-GDP ratio at a particular level $(\mathrm{d})$, is a function of the nominal growth rate of GDP $(\mathrm{g})$. This steady-state relationship can be derived as follows.

A first approximation of the relationship between debt and the current account (i.e. abstracting from revaluation effects) is as follows:

$$
D_{t}=D_{t-1}+C A_{t}
$$

where $\mathrm{D}$ denotes the level of net foreign debt and CA the current account balance.

yields:

Dividing both sides of [1] by Y (nominal GDP), and assuming that Y grows at a constant rate g,

$$
\frac{D_{t}}{Y_{t}}=\frac{D_{t-1}}{Y_{t-1}(1+g)}+\frac{C A_{t}}{Y_{t}}
$$

If now a variable in lower script denotes a ratio in terms of GDP, it follows from [2] that:

$$
d_{t}=\frac{d_{t-1}}{(1+g)}+c a_{t}
$$

Thus, in the long run (when $d_{t}=d_{t-1}$ ), the current account ratio required to stabilise net debt in terms of GDP is:

$$
c a=d \frac{g}{(1+g)}
$$

In the baseline scenario where $g=0.05$ and $c a=-0.05$, it follows that $d=-1.05$. i.e. net foreign debt stabilises at 105 per cent of GDP. Similarly, in the scenario where $c a$ improves to $-0.03, d$ stabilises at -0.63 (net foreign debt equivalent to 63 per cent of GDP). 


\section{BIBLIOGRAPHY}

CAMPA, J.M. and L.S. GOLDBERG (2002), "Exchange rate pass-through into import prices: A macro or micro phenomenon?", NBER Working Paper, No. 8934, May.

CLINE, W.R. (1989), United States external adjustment and the world economy, Institute for International Economics, Washington.

DE MELLO, L., P. KONGSRUD and R. PRICE (2004), "Saving behaviour and the effectiveness of fiscal policy", OECD Economics Department Working Papers, forthcoming.

DE SERRES, A. and F. PELGRIN (2003), "The decline in private savings rates in the 1990s in OECD countries: How much can be explained by non-wealth determinants?", OECD Economic Studies, No. 36 .

DOWNES, P., A. DREW and P. OLLIVAUD (2003), "The OECD medium-term reference scenario: Economic Outlook 74", OECD Economics Department Working Papers, No. 372.

GAGNON, J.E. (2003), "Long-run supply effects and the elasticities approach to trade", Board of Governors of the Federal Reserve System, International Finance Discussion Paper, No. 754.

GREENSPAN, A. (2003), Remarks by Chairman Alan Greenspan, Federal Reserve Board, at the $21^{\text {st }}$ Annual Monetary Conference, cosponsored by the Cato Institute and The Economist, Washington, D.C., 20 November.

GREENSPAN, A. (2004), Remarks by Chairman Alan Greenspan, Federal Reserve Board, Current Account, before the Economic Club of New York, New York, 2 March.

HOOPER, P., K. JOHNSON and J. MARQUEZ (1998), "Trade elasticities for G-7 countries”, Board of Governors of the Federal Reserve System Discussion Papers, No. 609.

HOUTHAKKER, H.S. and S.P. MAGEE (1969), "Income and price elasticities in world trade", The Review of Economics and Statistics, Vol. 51, No. 2.

KRUGMAN, P. (1989), "Differences in income elasticities and trends in real exchange rates", European Economic Review, Vol. 33, No. 5.

MANN, C. (1999), Is the US Trade Deficit Sustainable?, Institute for International Economics, Washington.

MANN, C. (2002), "Perspectives on the US current account deficit and sustainability", Journal of Economic Perspectives, Vol. 16, No. 3.

MANN, C. (2003), "The US current account, new economy services and implication for sustainability", paper initially prepared for the conference organised by the Institute for International Studies: European Forum, Stanford University, October 2002, Revised August 2003. http://www.iie.com/publications/papers/mann0104.pdf

MARQUEZ, J. (2002), Estimating Trade Elasticities, Kluwer Academic Publishers, Boston. 
OBSTFELD, M. and K. ROGOFF (2000), "Perspectives on OECD economic integration: implications for US current account adjustment", Paper presented at the Federal Reserve Bank of Kansas City symposium on "Global Economic Integration: Opportunities and Challenges" in Jackson Hole, Wyoming, 24-26 August.

PAIN, N. and D. VAN WELSUM (2004), "International production relocation and exports of services", NIESR Discussion Papers, No. 237.

PAIN, N. and K. WAKELIN (1998), "Export performance and the role of foreign direct investment", The Manchester School Supplement, 66.

STERN, R.M., A.S. DEARDORFF, S.H. HYMANS and C. XIANG (2001), "Forecasting US trade in services", in Services in the International Economy, R.M. Stern (ed.), Ann Arbor: University of Michigan Press, 53.

WREN-LEWIS, S. and R.L. DRIVER (1998), "Real exchange rates for the year 2000", Institute for International Economics, Policy Analyses in International Economics 54. 


\section{WORKING PAPERS}

The full series of Economics Department Working Papers can be consulted at www.oecd.org/eco/Working_Papers/

389. Product Market Competition and Economic Performance in Norway (May 2004) Jens Høj and Michael Wise.

388. Product Market Competition and Economic Performance in Sweden (May 2004) Deborah Roseveare, Martin Jørgensen and Lennart Goranson

387. Product Market Competition and Economic Performance in Japan (May 2004) Jens Høj and Michael Wise

386. Migration and Integration of Immigrants in Denmark (May 2004) Deborah Roseveare and Martin Jørgensen

385. Factors Driving Risk Premia (April 2004) Torsten Sløk and Mike Kennedy

384. Rationalising Public Expenditure in the Slovak Republic (March 2004) Rauf Gönenç and Peter Walkenhorst

383. Product Market Competition and Economic Performance in Switzerland (March 2004) Claude Giorno, Miguel Jimenez and Philippe Gugler

383. Concurrence sur les Marchés de Produits et Performance Économique en Suisse (Mars 2004) Claude Giorno, Miguel Jimenez and Philippe Gugler

382. Differences in Resilience between the Euro-Area and US Economies (March 2004) Aaron Drew, Mike Kennedy and Torsten Sløk

381. Product Market Competition and Economic Performance in Hungary (March 2004) Carl Gjersem, Philip Hemmings and Andreas Reindl

380. Enhancing the Effectiveness of Public Spending: Experience in OECD Countries (February 2004) Isabelle Joumard, Per Mathis Kongsrud, Young-Sook Nam and Robert Price

379. Is there a Change in the Trade-Off between Output and Inflation at Low or Stable Inflation Rates? Some Evidence in the Case of Japan (February 2004) Annabelle Mourougane and Hideyuki Ibaragi

378. Policies bearing on product market competition and growth in Europe (January 2004) Carl Gjersem

377. Reforming the Public Expenditure System in Korea (December 2003) Young-Sook Nam and Randall Jones

376. Female Labour Force Participation: Past Trends and Main Determinants in OECD Countries (December 2003) Florence Jaumotte

375. Fiscal Relations Across Government Levels (December 2003) Isabelle Joumard and Per Mathis Kongsrud

374. Health-Care Systems: Lessons from the Reform Experience (December 2003) Elizabeth Docteur and Howard Oxley 
373. Non-Tariff Measures Affecting EU Exports: Evidence from a Complaints-Inventory (December 2003) Peter Walkenhorst and Barbara Fliess

372. The OECD Medium-Term Reference Scenario: Economic Outlook No. 74 (November 2003) Peter Downes, Aaron Drew and Patrice Ollivaud

371. Coping with Ageing: A Dynamic Approach to Quantify the Impact of Alternative Policy Options on Future Labour Supply in OECD Countries

(November 2003) Jean-Marc Burniaux, Romain Duval and Florence Jaumotte

370. The Retirement Effects of Old-Age Pension and Early Retirement Schemes in OECD Countries (November 2003) Romain Duval

369. Policies for an Ageing Society: Recent Measures and Areas for Further Reform (November 2003) Bernard Casey, Howard Oxley, Edward Whitehouse, Pablo Antolin, Romain Duval, Willi Leibfritz

368. Financial Market Integration in the Euro Area (October 2003) Carl Gjersem

367. Recent and Prospective Trends in Real Long-Term Interest Rates: Fiscal Policy and Other Drivers (September 2003) Anne-Marie Brook

366. Consolidating Germany's finances: Issues in public sector spending reform (September 2003) Eckhard Wurzel

365. Corporate Taxation of Foreign Direct Investment Income 1991-2001 (August 20030) Kwang-Yeol Yoo

364. Indicator Models of Real GDP Growth in Selected OECD Countries (July 2003) Franck Sédillot and Nigel Pain

363. Post-Crisis Change in Banking and Corporate Landscapes - the Case of Thailand (July 2003) Margit Molnar

362. Post-Crisis Changes in Banking and Corporate Landscapes in Dynamic Asia (June 2003) Margit Molnar

361. After The Telecommunications Bubble (June 2003) by Patrick Lenain and Sam Paltridge

360. Controlling Public Spending in Iceland (June 2003) Hannes Suppanz

359. Policies and International Integration: Influences on Trade and Foreign Direct Investment (June 2003) Giuseppe Nicoletti, Steve Golub, Dana Hajkova, Daniel Mirza, Kwang-Yeol Yoo

358. Enhancing the Effectiveness of Public Spending in Finland (June 2003) Philip Hemmings, David Turner and Seija Parviainen

357. Measures of Restrictions on Inward Foreign Direct Investment for OECD Countries (May 2003) Stephen S. Golub

356. Tax Incentives and House Price Volatility in the Euro Area: Theory and Evidence (May 2003) Paul van den Noord 